\title{
Evidence for subsurface origin of boulder caves, roofed slots and boulder-filled canyons (Broumov Highland, Czechia)
}

\author{
Filip Duszyński, Kacper Jancewicz, and Piotr Migoń* \\ Institute of Geography and Regional Development, University of Wrocław, pl. Uniwersytecki 1, 50-137 Wrocław, Poland
}

\begin{abstract}
The backslope of a sandstone cuesta in the Broumov Highland (Czechia) is cut by a complex network of canyons. Long sections of canyons have thick boulder fills which are difficult to reconcile with simple rock fall and talus development scenario. Boulder caves occur within these fills and their lowermost parts are drained by streams that evacuate fine loose sandy material produced by weathering and mechanical erosion. These boulder fills are explained as largely in situ, residual features, left after subsurface selective disintegration of rock mass, mainly joint-guided, and removal of grains by underground water. Evacuation of fines leaves voids into which overlying blocks subside but the voids may be spacious enough (largely because the rock blocks are so large) to connect into penetrable caves. Results of an analogous process may be observed along canyon walls where more densely jointed sandstone compartments develop into roofed slots. Additional evidence for an important role of subsurface processes is provided by closed depressions in the inter-canyon areas. A model of canyon evolution is offered, alternative to the existing models implying surface fluvial erosion or retreat due to spring sapping. Its applicability is limited by the thickness of a sandstone package but the origin of canyons a few tens of metres deep (up to $100 \mathrm{~m}$ or so) may be explained.
\end{abstract}

Keywords: Sandstone, non-karstic caves, canyons, geomorphology, Sudetes

Received 27 May 2018; Revised 27 August 2018; Accepted 27 August 2018

Citation: Duszyński F., Jancewicz K. and Migoń P., 2018. Evidence for subsurface origin of boulder caves, roofed slots and boulder-filled canyons (Broumov Highland, Czechia). International Journal of Speleology, 47 (3), 343-359. Tampa, FL (USA) ISSN 0392-6672

https://doi.org/10.5038/1827-806X.47.3.2209

\section{INTRODUCTION}

Subterranean voids due to rock dissolution, collapse features into the voids and narrow canyons are among distinctive karst features, typifying many karst areas in the world. Long considered endemic to highly soluble calcareous and gypsum rocks, they are increasingly recognized in siliceous rocks as well, mainly within regularly jointed sandstones (Wray, 1997; Young et al., 2009; Wray \& Sauro, 2017). However, their dissolution origin, while proved without doubt at some sites, is not necessarily applicable to all real-world examples. Hence, while the concept of silicate karst has gained international recognition (Ford \& Williams, 2007), the somewhat vague and poorly defined term of pseudokarst (Eberhard \& Sharples, 2013) is still in use. Despite ambiguity, it is agreed that it is particularly pertinent to geomorphic features, both surface and underground, similar to those in the karst areas proper but of different origin. The challenge is to identify processes at work, responsible for the emergence of these features and a task of particular interest seems to be an inquiry whether rock dissolution is the only mechanism which can initiate and guide the evolution of subterranean voids and their surface manifestations. In this context, Bruthans et al. (2012a, b) advocated subsurface removal of loosened sand along fracture zones at depth to account for the origin of narrow clefts within rock cities (see also Migoń et al., 2017), whereas Duszyński et al. (2016) pointed out an important role of sand evacuation from inside the jointed sandstone mass in inducing block tilting, sagging and collapses.

In this paper we continue this line of research, investigating geomorphology of the canyon network that typifies the backslope of a prominent sandstone cuesta escarpment of the Broumov Highlands (northern Czechia) (Fig. 1). In fact, the area, also known for its numerous picturesque rock outcrops and apparently non-karstic caves, has long been presented as a 'classic' pseudokarst terrain (Vitek, 1979; Demek et al., 2006), although more informed investigations into the mechanisms of formative processes were almost lacking. Reconnaissance work 

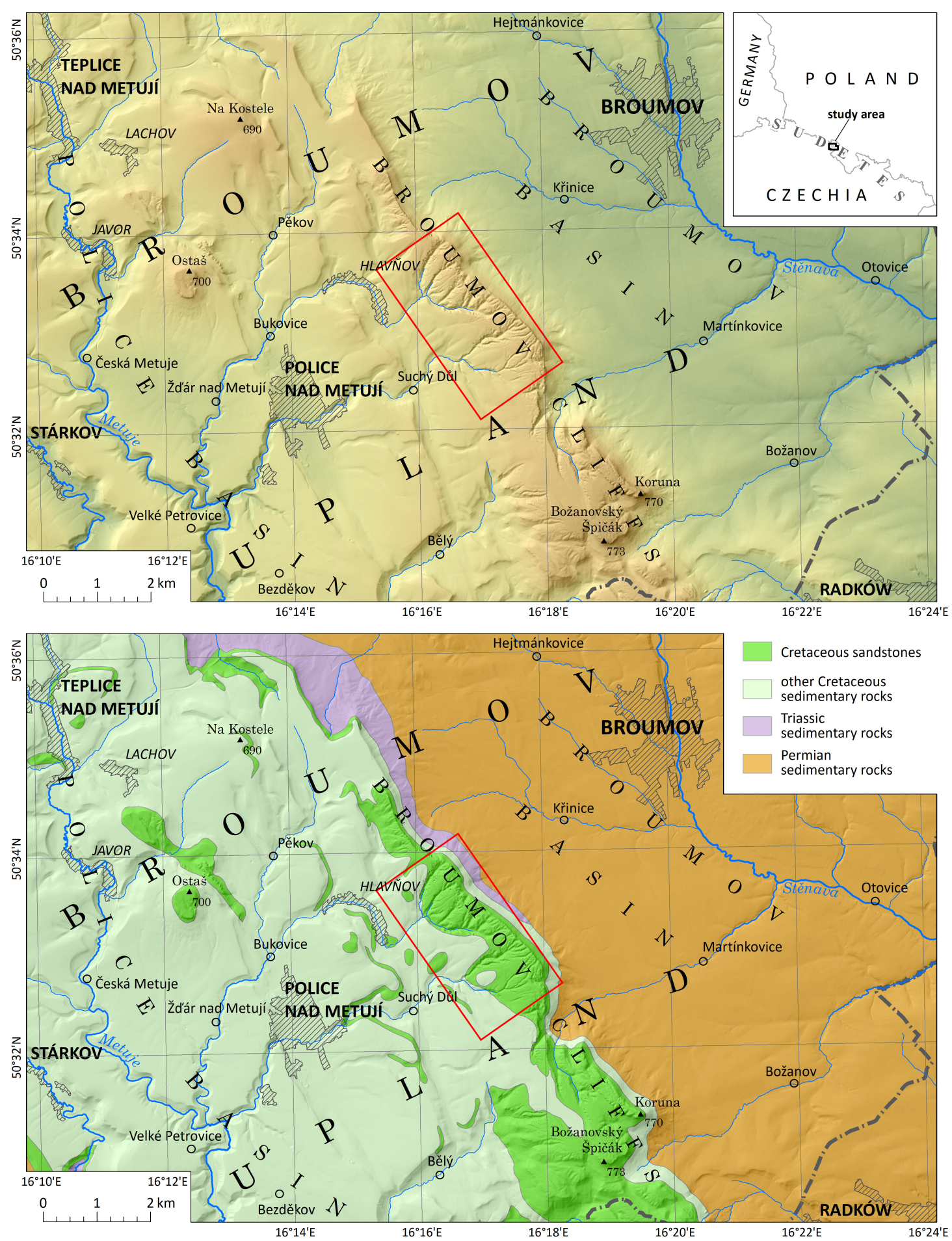

Fig. 1. Study area. The Broumov Cliffs are the front part of a cuesta of NW-SE extension.

casted some doubts if the canyons, many boulderfilled to the point of inaccessibility, can be simply explained as products of fluvial erosion and rock slope collapses alone. Hence, more systematic survey was attempted and an alternative hypothesis tested. This hypothesis stated that some sections of the canyons owe their origin to initially subterranean removal of sand and subsequent subsidence of the overlying rock masses into emerging voids.

This hypothesis-driven research is reflected in the structure of this contribution. First, the context is set through the literature review of the origin of two most characteristic landforms of the area, i.e., boulder caves and canyons. This is followed by more detailed presentation of the study area and methods used, including their limitations. The main part of the paper starts with presentation of two distinctive landforms found within the canyons - boulder caves and tributary slots to the main canyons, and then focused on larger features - the canyons themselves and their diversity. This approach is adopted in order to be matched by the discussion section, in which we upscale our interpretation from smaller to larger landforms. Supplementary observations come from inter-canyon areas. This field and DEM-based evidence allows us to discuss the validity of our alternative hypothesis and to propose an evolutionary model for further testing. In this way, although field data have been collected in one specific area, the model may possibly be of wider relevance and application, adding to the better understanding of peculiarities of sandstone geomorphology. 


\section{LITERATURE REVIEW}

\section{Boulder caves - origin in the light of existing literature}

While large, wide open spaces under overhanging singular boulders, usually termed rock shelters, are not considered as caves, interconnected voids between many boulders, big enough to be penetrable by humans, are often included into classifications of non-karstic caves (e.g., Vitek, 1980). The most comprehensive approach was offered by Bella (2011), who distinguished a group of 'caves due to accumulation of fallen and slid rock blocks and boulders' (our translation). This description is consistent with the assumption that boulder caves are synonymous with talus caves, implying that their origin is linked with the delivery of boulders from the upper slope due to mass movements and their unordered deposition. This interpretation of boulder caves is widely present in the voluminous Czech literature about non-karstic caves in sandstone terrains, including the Broumov Highland (Vitek, 1979, 1980). Both caves directly under rock cliffs and further away, within valley bottoms, were explained in this way. However, Bella (2011) also remarked that these caves may be enlarged due to removal of fine fraction by streams flowing in the valley bottoms, under the boulders. This scenario was also acknowledged by Striebel (1995, p. 48) who, beside 'boulder caves' from rock falls, distinguished 'erosion boulder caves' and explained them as follows: 'If a rock slide occurs within a narrow, water-carrying gorge, the creek is first blocked by boulders. It erodes these boulders by finding a new way and forms watercarrying cavities and caves'. Somehow similar in origin seem to be 'purgatory caves' (Halliday, 2004) a term apparently endemic to US usage and not really present in international literature. They are presented as equivalents of 'gorge bottom caves'.

However, not all boulder caves can be equated with talus caves, understood as genetically linked with rock slope failures. Sjöberg (1987) hypothesized that large cave systems within broken outcrops of basement rocks in Sweden were produced by high-magnitude earthquakes which accompanied the postglacial isostatic rise of Scandinavia. In granites, known to be subject to selective deep weathering, more complex, two-phase history of some boulder caves is envisaged (e.g., Shaw, 1980; Striebel, 1995, 2008; Vidal Romaní \& Vaqueiro Rodrigues, 2006; Eszterhás, 2009). In the first phase, separation of the rock mass into solid compartments (corestones) and loose sandy-gravelly regolith (grus) occurs. This is followed by removal of grus by running water and shallow mass wasting, so that voids in between the residual boulders become open. In specific situations the cumulative length of interconnected chambers may reach a few tens of metres (Striebel, 2008).

\section{Canyons - pathways of evolution}

Canyons - vertically-sided valleys being tens up to hundreds of metres deep - belong to the most distinctive features of sandstone terrains (Young \& Young, 1992). Whereas the presence and morphology of these forms are generally controlled by the patterns of discontinuities (Gregory, 1950), their genesis and evolutionary pathways appear far more complicated. Ideas presented so far were based mainly on the study of spectacular landforms typifying the landscape of the Colorado Plateau (e.g., Laity \& Malin, 1985; Howard \& Kochel, 1988; Laity, 1988). A growing interest in the topic in the 1980s resulted in a concept of the dominant role of groundwater flow and seepage erosion (Laity \& Malin, 1985; Laity, 1988). Accordingly, where sandstone is highly permeable and well-jointed and the dip of the strata is less than $4^{\circ}$ (a common situation within the Navajo Sandstone of the Colorado Plateau), seepage-related phenomena become the fundamental mechanism of evolution of canyon networks. In such a geological situation, the water easily percolates through sandstone until it reaches an impermeable layer. At the lithological contact water flows horizontally, with the hydrological gradient, finally emerging at the cliff face as a 'seepage zone'. The enhanced weathering in the lower part of the rock wall leads to the development of deep alcoves (e.g., Campbell, 1973). At the critical point an overhang collapses and the valley head retreats. The colluvium quickly disintegrates into loose sand as the sandstone loses its firmness during impact (e.g., Schumm \& Chorley, 1966; Laity, 1988). Such comminuted material is easily removed by erosional processes and wind action so that the canyon does not become buried. The typical features of canyon morphology due to sapping are huge amphitheatrical heads lined with vertical rock walls, very steep valley sides, which are straight in plan showing clear adjustment to the vertical joints, as well as distinctive parallelism of subsequent tributaries (e.g., Gregory, 1917; Laity, 1988). The development of canyons due to groundwater flow is considered to consist of two phases. At first, canyons increase in length when the valley head is actively retreating. Later on, the canyon widens by collapses from valley sides when the catchment area becomes too little to effectively recharge the groundwater system (Laity, 1988).

Although sapping canyons gained the greatest scientific interest, they should be perceived as rare rather than typical erosional features in sandstone (Young \& Young, 1992). In fact, canyons are usually developed by stream erosion which acts predominantly along the surfaces of discontinuities, leading to their widening by successive collapses from the valley sides (Young \& Young, 1992). The resultant morphology is starkly different from the one being the effect of groundwater processes. Erosional canyons may be much more open (Young \& Young, 1992) or characterized by long and narrow channels, such as the western tributaries of the Escalante River (Colorado Plateau) described by Laity \& Malin (1985). In the latter case the reason for the dominance of surface runoff over groundwater sapping is possibly the greater dip of the strata (Laity, 1988). Another typical feature of the Colorado Plateau - very narrow 'slot canyons' - are also believed to be the result of stream erosion along joints in localities, where 
sandstone is not very well cemented but strong enough to form vertical walls.

It needs to be underlined that in the newest literature the distinction between sapping and stream erosion genesis of canyons is believed not to be so clear. For example, Lamb et al. (2006) showed that the retreat of the amphitheatre-headed canyons may not be the sole result of seepage erosion, but plunge pool erosion may also play an important role.

\section{STUDY AREA}

The study area is located in northern Czechia, in the central part of the Sudetes mountain range that constitutes the north-eastern rim of the Bohemian Massif and straddles the Czech/Polish border (Fig. 1). Geographically, it lies within the extent of the Broumov Highland (Broumovská vrchovina, in Czech). Geologically, this part of the Sudetes is a large intramontane trough filled by thick successions of Permian, Lower Triassic and Upper Cretaceous sedimentary rocks, deposited in terrestrial (Permian - Triassic) and marine environment (Cretaceous). The Cretaceous succession consists of alternating sandstone and mudstone/marl beds, the former occurring in packages exceeding $100 \mathrm{~m}$ thick (Tásler et al., 1979). Sandstones are predominantly quartzose, medium- to coarse-grained, with minor admixture of partly weathered feldspar and kaolinitic cement. Regular orthogonal jointing and the presence of largescale cross bedding are characteristic features of the Middle Turonian sandstones which are of particular interest in this paper.

The Middle Turonian sandstones crop out in the eastern part of the Broumov Highland and being apparently much more resistant to weathering and erosion than the underlying Permian, Triassic and Cretaceous beds, they form a prominent cuesta escarpment known as the Broumov Cliffs (Broumovské stěny). The cuesta has NW-SE extension, following the strike of the Middle Turonian beds, with the frontal slope facing $\mathrm{NE}$ and the backslope inclined to SW. The dip of strata is $10-25^{\circ}$ whereas the general inclination of the backslope at interfluves is about $5^{\circ}$. The thickness of the sandstone caprock is c. $80 \mathrm{~m}$ and the height of rocky precipices at the cuesta front reaches $40-50 \mathrm{~m}$. Jointing pattern is very regular, with two principal directions being $40-45^{\circ}$ and 130 $135^{\circ}$ (Stejskal et al., 2012). The former are clearly reflected in the topography, delineating rock fins projecting from the sides of the canyons and elongated depressions on the cuesta backslope, whereas the latter partly coincide with the alignment of the main canyons (Fig. 2).

The backslope of the cuesta is dissected by a network of canyons, organized in two main separate systems (Fig. 3). The northern system of Hlavňovský potok includes the trunk valley that runs east to west, thus diagonal to the general inclination of the Broumov Cliffs backslope, three major tributary canyons: Kovár̆ova rokle (Czech rokle = gorge, canyon), Písková rokle and Nemecká rokle, and several smaller valleys. The southern system is less regularly arranged, with Hájkova rokle and Hruškova rokle as the main arteries, each receiving many short tributary troughs and slots and dividing into several branches in the headwater parts.
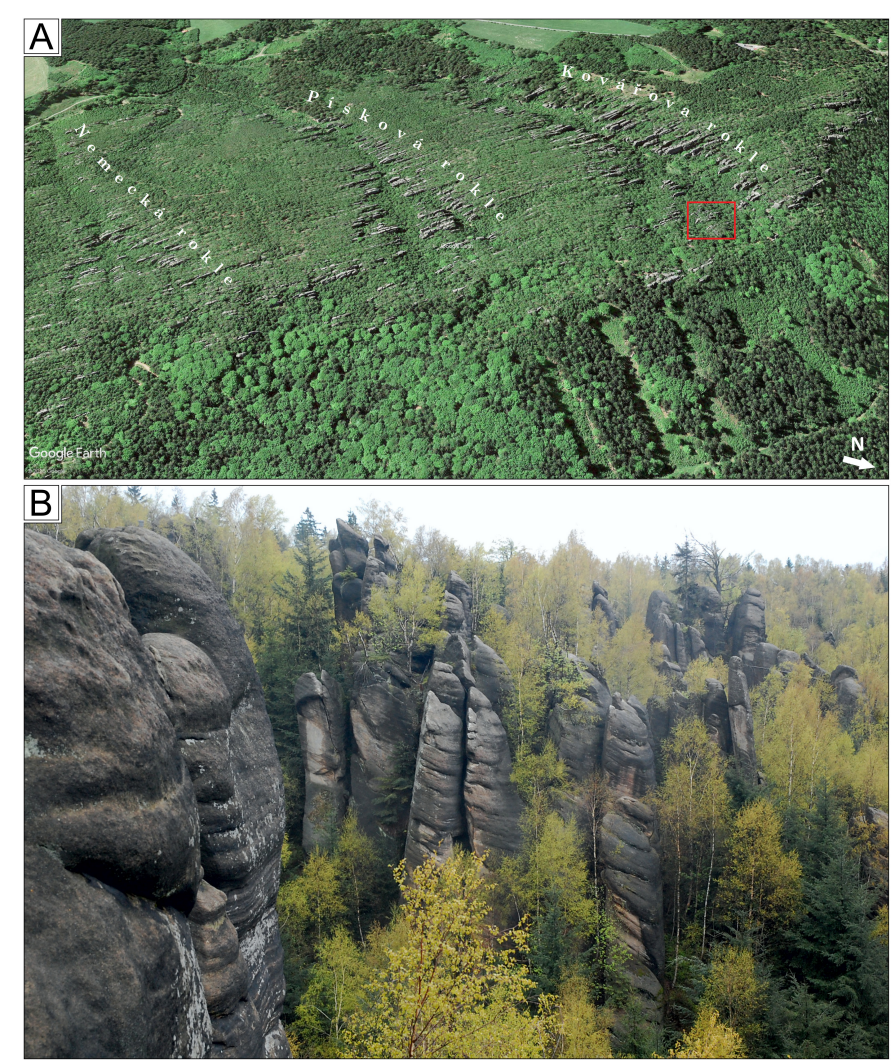

Fig. 2. Alternating sandstone fins and linear depressions perpendicular to the canyon axis, delineated by NW-SE trending joints, are characteristic for the cuesta backslope. A) aerial view (red square show the location of features shown on Fig. B) (Source of image: () Google Earth); B) eastern side of the Kovářova Gorge.

\section{DATA SOURCE AND METHODS}

This study is based on field and desk research, using high-resolution digital terrain model (DTM). Despite the nominally high resolution of DTMs, it failed to capture geomorphological details of the canyons and interfluves (see below), and field work was necessary. It involved landform recognition and mapping within the main and tributary canyons, penetration of side slots, and verification of terrain models returned by DTMs. It is important to underline that the canyon maze on the cuesta backslope is all within forest vegetation, locally so thick and dense that it is non-penetrable. In addition, in valley floors trees and undergrowth grow directly on large (often $>5 \mathrm{~m}$ long/high), chaotically distributed boulders, hiding geomorphic details from sight. In a number of places, safety reasons precluded visits to certain parts of the gorges. Thus, a complete ground coverage of the area was not possible.

Morphometric analysis was conducted using LiDAR-based Czech DTM of $1 \mathrm{~m}$ resolution - Digitální model reliéfu České republiky 5 generace (DMR 5G) and SAGA-GIS 6.3.0 software (Conrad et al., 2015). It included calculation of Morphometric Protection Index (MPI), which is an equivalent to the positive openness parameter (Yokoyama et al., 2002), and Terrain Ruggedness Index (TRI) (Riley et al., 1999). The MPI parameter, which considers the relative relief in the 


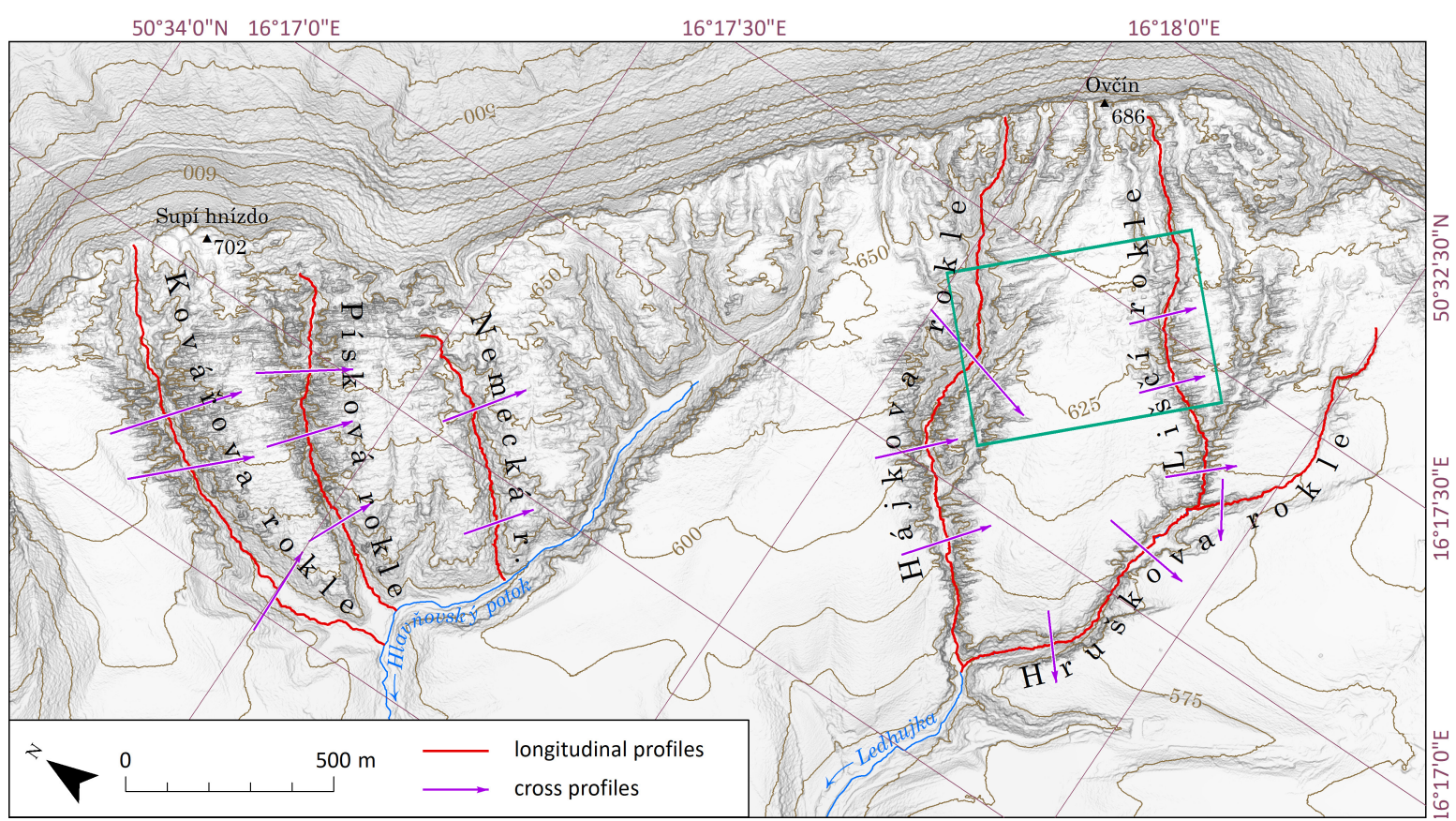

Fig. 3. Canyon network on the backslope of the Broumov Cliffs cuesta. Longitudinal and cross profiles of selected canyons are shown on Fig. 9. Green rectangle indicates the position of Figure 11.

surrounding of a cell by analysing the vertical angle between points, was used in order to identify deeply incised and narrow (hence, protected) gorge sections (some sections of which were impossible to access). Desk work also included semi-automatic delineation of selected gorge floors, which was achieved by using the criterion of local maximum height $1.5 \mathrm{~m}$ above theoretical stream lines. As a result, it was possible to present spatial variability of floor roughness, represented by TRI values. TRI is expressed as the sum of change of elevation between the central cell and its eight neighbours and we assumed that boulder fills may give specific signatures, different from those for either flat alluvial floors or narrow sections bounded by rock walls. The model also helped to recognize closed depressions of various size and depth.

\section{VALLEY FLOOR BOULDER CAVES - OCCURRENCE AND CHARACTERISTICS}

Boulder (talus) caves have been reported from several places in the Broumov Highland and two largest caves of this kind are located within valley floors (Kopecký, 1990), although none in the specific canyon area reported in this study. Teplická Cave, a few kilometres west of the town of Teplice nad Metuji (see Fig. 1), is 1,065 $\mathrm{m}$ long in total and described in the following way: "It is a complex of narrow passages alternating with more spacious chambers surrounded by huge (max. $10 \mathrm{~m}$ in size) sandstone blocks overlying the original valley bottom in a thickness of $\max .25 \mathrm{~m}$. The bottom of the cave is an active stream channel or a flood-water channel with sandy fluvial deposits and rock debris. In places, cave corridors are formed in two or three levels one above another" (Kopecký \& Jenka, 2013, p. 9). It occupies a section of the valley floor c. $250 \mathrm{~m}$ long. Another sizeable cave, Pod Luciferem Cave within the front scarp of the Broumov Cliffs cuesta, just south of the canyon area, is $400 \mathrm{~m}$ long and has a valley floor setting too. Kopecký \& Jenka (2013, p. 11) remarked that "The subterranean stream flows across a rocky cave bottom but occasionally disappears, sinking to sand, debris and coarse talus". No specific comments about the origin of the two caves were offered, apart from the general statement that they both originated in "blocky talus", without specifying the origin of the talus.

Although systematic survey of underground spaces was not the part of this study, boulder caves were frequently encountered while performing geomorphological mapping of the backslope canyons. The best known cave of this type is Kovarna in the Kovárova Gorge. It is composed of a large chamber, c. $10 \times 8 \mathrm{~m}$ in dimensions and more than $5 \mathrm{~m}$ high, with blind clefts radiating from the chamber. The roof is provided by tall sandstone towers, tilted towards the valley and leaning against one another (Fig. 4A). The cave chamber is located exactly in the axis of the gorge and the stream goes through it, disappearing into sandy floor. Going downstream, however, one has to climb up a step a few metres high, so there is no consistent downstream slope of the cave floor. A much smaller, but morphologically similar boulder cave is located in the axis of Pisková Gorge. This one too is drained by a stream, which descends over $3 \mathrm{~m}$ high rock step under the roof of several large boulders.

In the southern canyon network, two fairly large, penetrable boulder cave systems occur in the floor of the Hruškova Gorge (Fig. 4B). The upper one is almost immediately downstream from a distinctive head of the canyon section and consists of a series of chambers and passages at several levels with the total length of a few tens of metres. The lower one is located in the middle section of the gorge and, although smaller, it too represents a maze of voids at different levels. Another large boulder cave is located in the tributary canyon to the Hájkova Gorge. The system of chambers allows penetration down to the canyon floor, which is covered by extensive sandy sheets, deposited by a small stream which flows beneath the boulders. The 

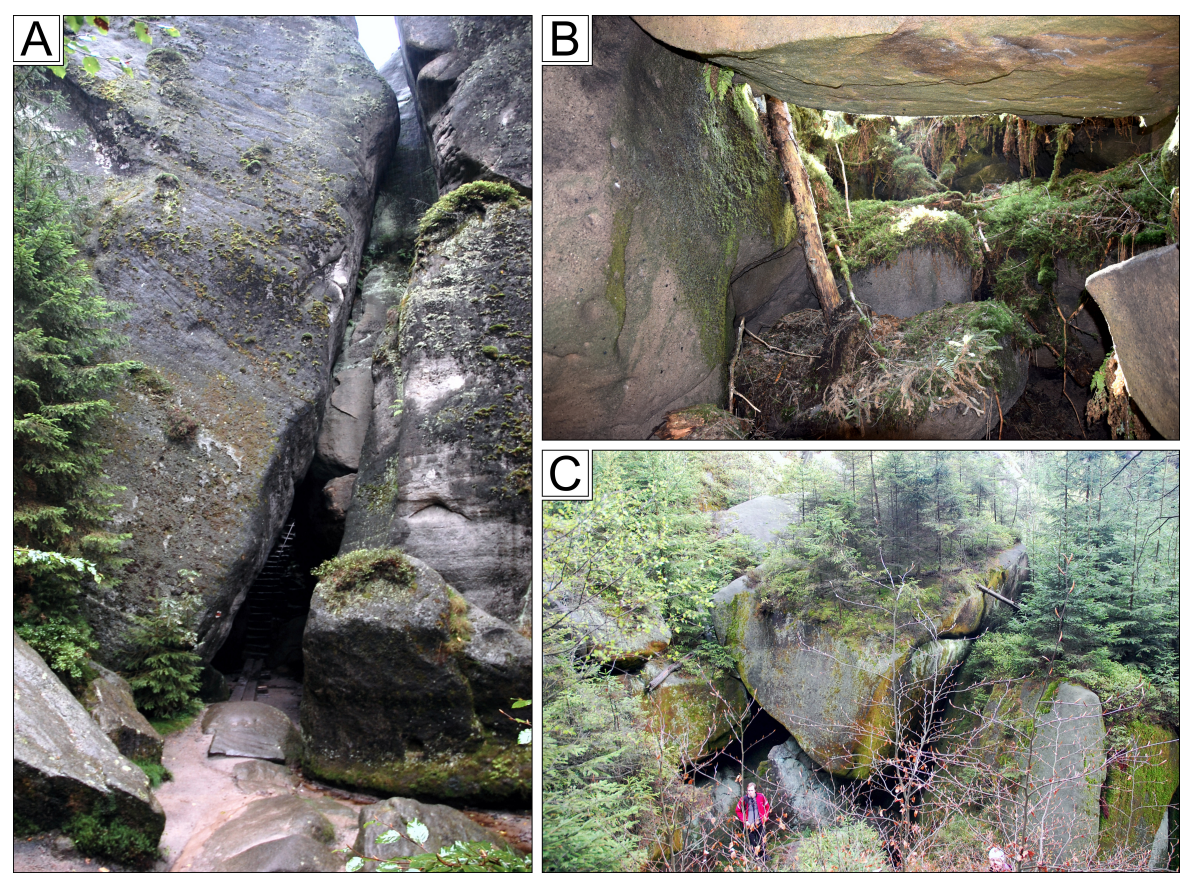

Fig. 4. Examples of caverns. A) Kovárna in the Kovářova Gorge, due to leaning of a rock tower; B) entrance part of a boulder cave in the upper part of the Hruškova Gorge; $C$ ) cave openings within the massive boulder fill in the middle section of the Kovárova Gorge.

most impressive cave, almost entirely beneath one huge boulder, extends over a distance of more than $10 \mathrm{~m}$.

The number of boulder caves in the canyon floors is likely to be higher but their penetration was not always possible. For example, in the lower part of the Kovárova Gorge it was possible to identify an entrance to an apparently large chamber from a footbridge across the boulder fill to the Marianská Cave and to several other systems from the valley side trail (Fig. 4C).

\section{SLOTS - ROOFED AND UNROOFED}

The backslope canyons of the Broumov Cliffs do not have straight rims, broadly parallel to the extension of a canyon. Instead, the canyon sides are modelled into alternating narrow ridges (fins) projecting into the canyon and intervening depressions (Fig. 2). This repetitive pattern reflects strong structural control and the presence of a distinctive NW-SE joint set, perpendicular or diagonal to the strike of the canyons. Field examination reveals that spacing of joints within this set is not uniform but varies from less than $1 \mathrm{~m}$ to more than $10 \mathrm{~m}$. The latter accounts for the occurrence of massive compartments (bastions), terminating with vertical walls more than $30 \mathrm{~m}$ high. More densely jointed bands are preferentially weathered and eroded, turning into depressions of different
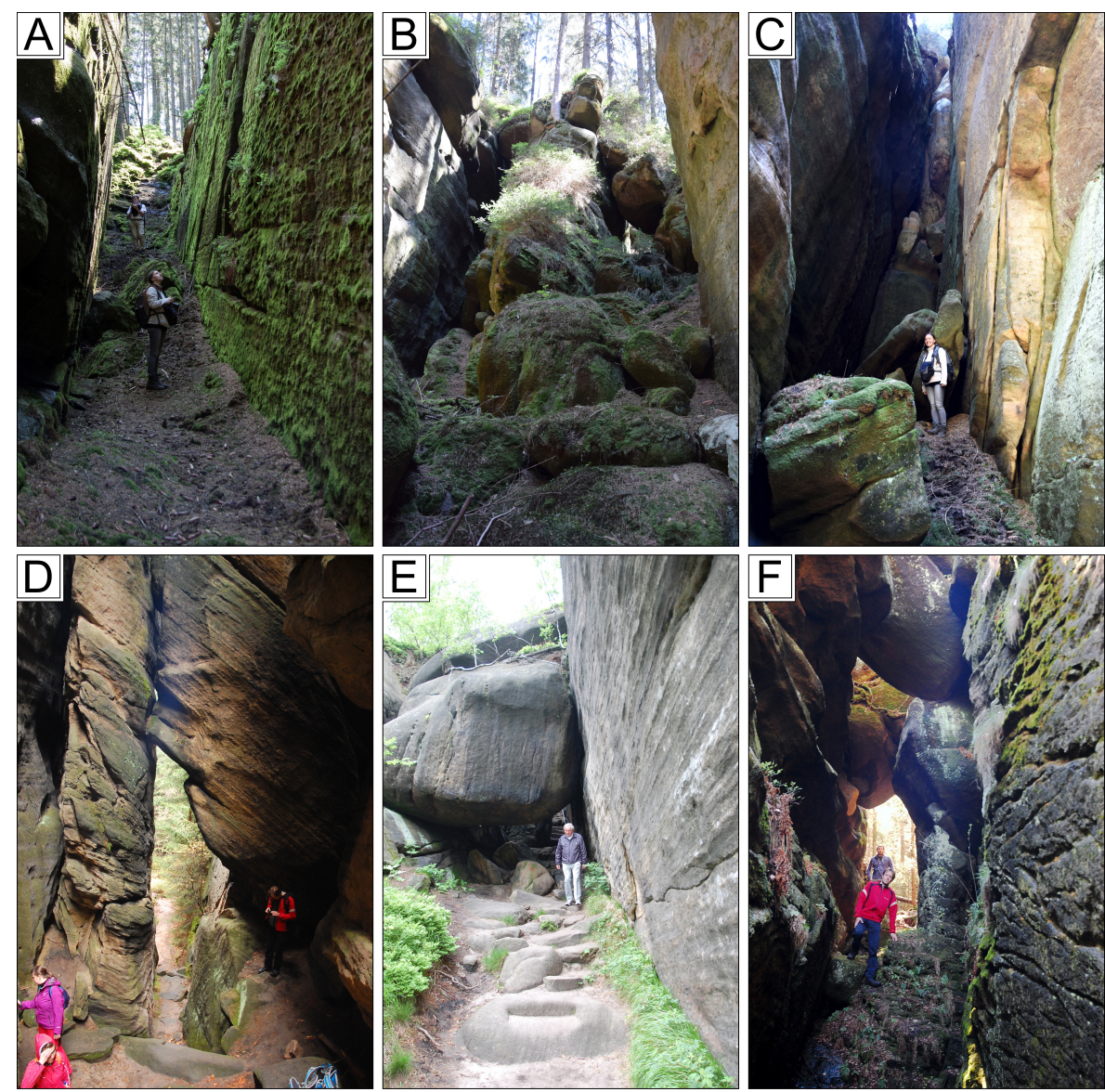

Fig. 5. Geomorphological diversity of slots perpendicular to the canyons. A) open, empty slot; B) boulder-filled slot; C) blind slot (notice small size of rock compartments at the end of the slot, compared to the massiveness of the walls); D) slot roofed by solid rock, as evidenced by the continuity of cross-bedding; E) slot roofed by a boulder that felt into the slot (notice vertical orientation of bedding planes); F) slot roofed by loose boulders. 
occur in the headwater parts of the Nemecká Gorge, in its eastern section (Fig. 6). Close to one another three slot features are present. Access to the gorge is provided by c. $150 \mathrm{~m}$ long depression, which halfway down turns into a $30 \mathrm{~m}$ cleft, with a $2.5 \mathrm{~m}$ rock step in the bottom and a roof made of a few big boulders (A on Fig. 6; also Fig. 5F). Further down a parallel, $7 \mathrm{~m}$ long passage goes into the sandstone cliff and continues as a narrow, impassable cleft under the roof of more massive sandstone compartment (B). Finally, slightly upstream one finds a $12 \mathrm{~m}$ long, partly roofed slot that ends blind (C). A large boulder cave in the gorge floor (D) complements the inventory at the site (Fig. 7). In the same gorge, one of the longest roofed slots, c. 50 $\mathrm{m}$ long, occurs near its exit, on its right-hand valley side, high above the valley floor. Another locality to see boulder-roofed slots is the lower section of the Hájkova Gorge, especially its eastern slope. Rounded boulders are suspended at different heights above the slot floor, from less than $1 \mathrm{~m}$ (thus forcing to crawl beneath them) to 3-4 $\mathrm{m}$ high. Both open and blind slots are present.

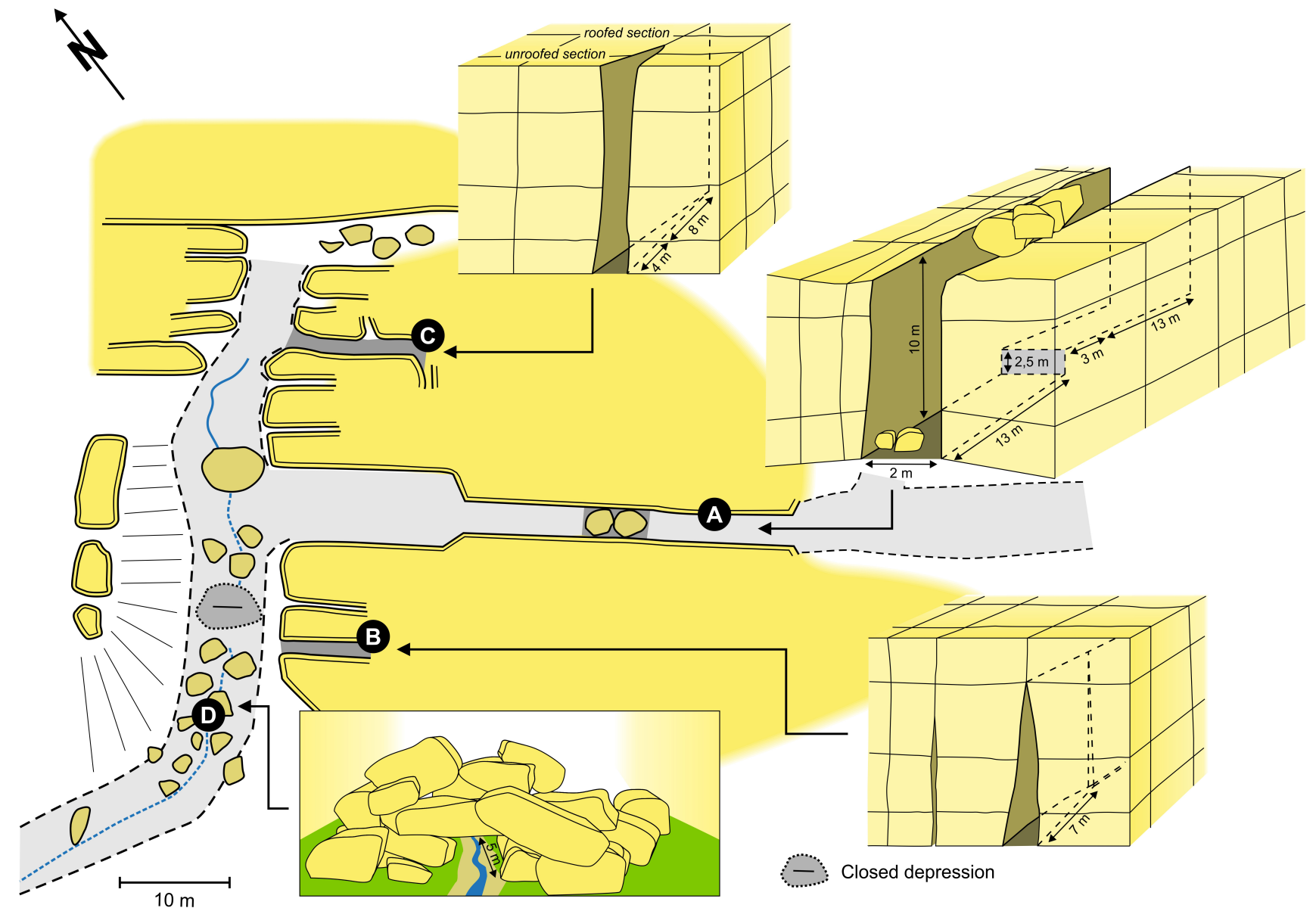

Fig. 6. Location sketch of a group of slots in the upper part of the Nemecká Gorge. Letter codes A-D explained in the text. Note that the scale is approximate.

\section{BACKSLOPE CANYONS}

\section{Geomorphic diversity}

Canyons incised into the backslope of the Broumov Cliffs cuesta are very diverse in terms of length, longitudinal profile, geometric pattern, cross-sectional characteristics (width, depth, slope inclination), landform inventories and hierarchy (Fig. 2, 8). Both relatively simple patterns (Kovářova Gorge) and compound networks with multiple tributary canyons (Lišči Gorge) exist, indicating that the history of the network must have been fairly complex. It seems significant that the northern gorges seem not be beheaded at the cuesta rim, in contrast to the systems of Hájkova Gorge and Lišči Gorge. The depth of canyons varies from $20 \mathrm{~m}$ in headwater parts to more than $50 \mathrm{~m}$ in the lower reaches. Each canyon is drained by a stream but channel landforms are poorly developed, discharges are invariably very low and the flows rather sluggish, except immediately downstream of waterfalls. The flow alternates between being visible at the surface and hidden below the boulders.

Longitudinal profiles of canyons are very uneven, with distinctive steps (knickpoints). They are particularly evident in the upper part of the northern system, where they separate rather gentle upper sections from steeper, more irregular middle and lower sections. The height of these steps reaches $10 \mathrm{~m}$ and they correspond to vertical rock walls across the canyons, with waterfalls (Fig. 9). By contrast, in the southern system the most distinctive steps, again with waterfalls, separate the tributary canyons of Hájkova Gorge and Lišči Gorge from the Hruškova Gorge. A distinctive knickpoint is present in the Hruškova Gorge itself (at $600 \mathrm{~m}$ length), marking the transition from a shallow trough upstream to the deep, boulderfilled section downstream.

Cross profiles are variable too, both within one gorge and if adjacent gorges are compared (Fig. 9). In the Kovárova Gorge one can distinguish between 


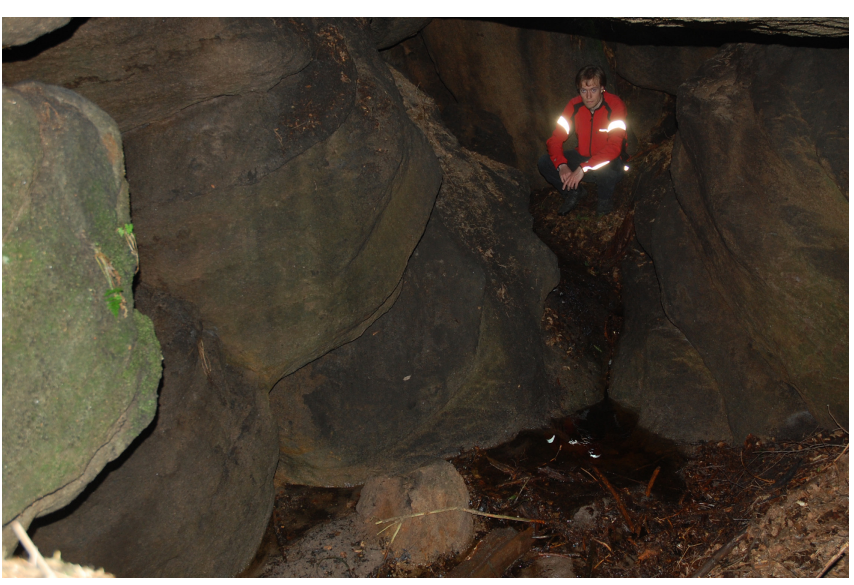

Fig. 7. Inside the boulder cave in the upper part of the Nemecká Gorge (D on Fig. 6). Note an active stream at the bottom of the chamber.

wide-floored sections at the upper and lower end and $\mathrm{V}$-shaped sections in between (Fig. 9A). The latter correspond with uneven long profile and thick boulder fill of the valley (see next section). The Nemecká Gorge, in turn, is quite consistently V-shaped along its length (Fig. 9C). The presence of flat-floored and more upstream $\mathrm{V}$-shaped reaches is also evident in the Hájkova Gorge (Fig. 9E). The Lišči Gorge and its side canyons are predominantly V-shaped (Fig. 9D).
However, field work revealed that the actual meaning of V-shaped cross-sections is different from what might be expected. They do not indicate significant bedrock downcutting going hand-in-hand with slope lowering processes. These valley sections are typified by massive boulder fills of the valley floor and the lower slopes, with vertical bedrock outcrops (walls, fins) only in the upper slope.

\section{Boulder-filled sections and their geomorphometric signatures}

Boulder-filled sections of the canyons are the most intriguing components of canyon morphology and special attention was paid to them. Although one might prefer a simple explanation that the fills are cumulative products of numerous rock falls from canyon walls, this scenario is not very likely. Occasional rock falls may have occurred as attested by infrequent scars and blind arches, but in general, canyon rock walls lack widespread evidence of rock slope failures. Sandstones in these localities tend to disintegrate grain-by-grain whereas large rock masses show backward rather than forward toppling. In addition, boulders making the fills are often fairly rounded, lack fractures expected from impact on the

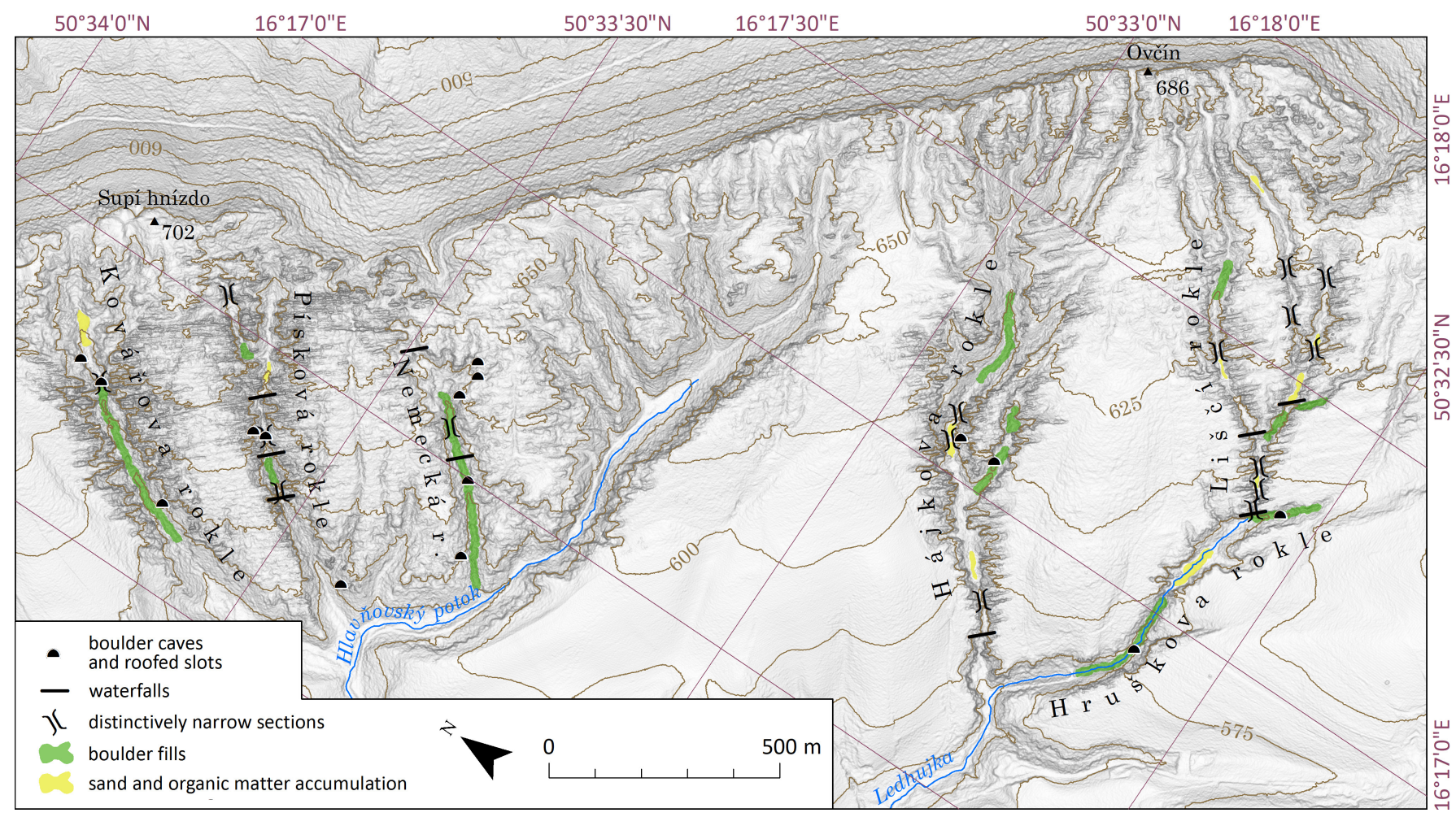

Fig. 8. Selected geomorphological features of the backslope canyons.

ground, and large size of voids in between them is hardly compatible with the effects of rock fall in rock of rather moderate intact strength. Unfortunately, detailed field mapping of boulder fills was not possible due to safety issues and restricted visibility in densely forested canyon bottoms, but penetrations of marginal parts of these sections revealed certain characteristics. Boulders are from 1-2 to 8-10 $\mathrm{m}$ long, with occasional giant compartments more than $15 \mathrm{~m}$ long. Voids in between them are $2-3 \mathrm{~m}$ high at least, often interconnected to form maze caves described before. Thickness of the fill may be estimated to range from a few to more than $10 \mathrm{~m}$, extending onto the slopes. Stream flow is usually observed at the bottom of the fill.

In addition to field observations, high-resolution DTM allowed us to extract some specific signatures of these sections. As indicated in the previous subsection, boulder fills correspond to the most irregular parts of canyon longitudinal profiles and V-shaped crosssections. They are well visible on graphs showing the downstream change of Morphometric Protection Index (MPI) which both reaches high numerical values, up to 1 , and - most of all - shows considerable variability 
(in excess of 0.4) over very short distances (Fig. 9). Finally, the range of Topographic Ruggedness Index (TRI) between 0.5 and 1.5 corresponds fairly well with the known occurrence of boulder fills (Fig. 10).

These two lines of information are the basis to show the distribution of boulder fills in the canyons (Fig. 8). They occupy approximately 35 per cent of the length of the Kovárova Gorge, 16 per cent of the
Písková Gorge length, 70 per cent of the Nemecká Gorge length, 20 per cent of the Hájkova Gorge length (only the section downstream of the confluence of headwater ravines is considered), and 23 per cent of the Hruškova Gorge length. Only in the Lišči Gorge the percentage of boulder-filled section is negligible. These figures indicate that the presence of boulder fills is a significant feature of the canyons.
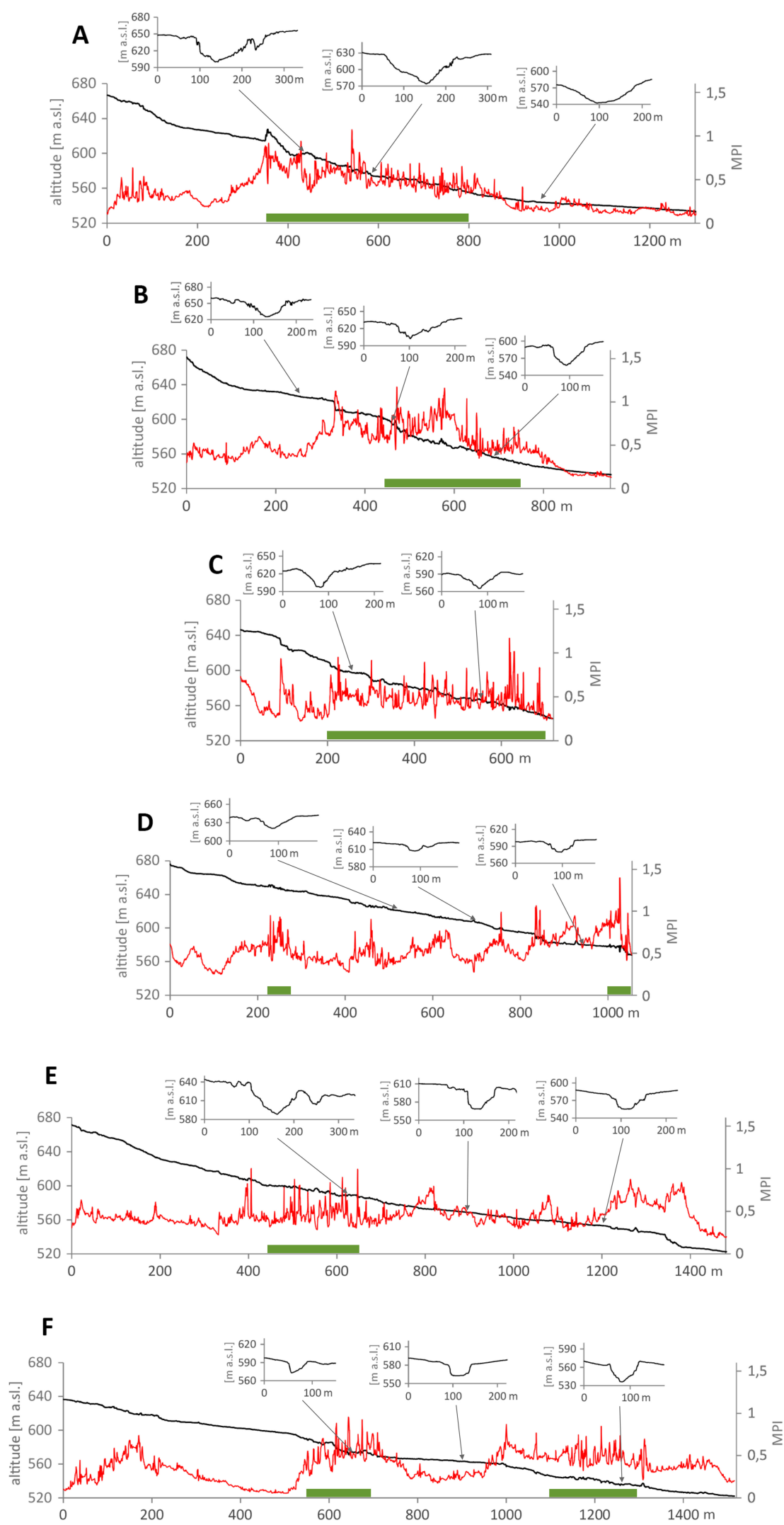

Fig. 9. Longitudinal and cross profiles of backslope canyons compared with the variability of the Morphometric Protection Index (see Fig. 3 for locations and text for explanation). A) Kovářova Gorge; B) Písková Gorge; C) Nemecká Gorge; D) Liščí Gorge; E) Hájkova Gorge; F) Hruškova Gorge. Green bars indicate sections of canyon floors with thick boulder fills. 


\section{GEOMORPHOLOGY OF INTER-CANYON AREAS}

Although considerable parts of inter-canyon areas show subdued, nearly planar relief (Fig. 2), these surfaces show diverse morphology too. This is best seen in the proximity of the canyons, where fins continue as progressively lower humps of exposed sandstone bedrock until they completely merge with the surrounding surface. Likewise, depressions become shallower in respect to fins (which maintain more or less uniform altitude of the top surface) and eventually disappear too. In specific places, such as between the headwater parts of the Kovárova and Písková gorges, humps and depressions continue across the local water divide. Narrow joint-guided passages allow to cross these labyrinths of elevations and hollows. By contrast, large areas between the Hájkova Gorge and the Lišči Gorge show negligible relief.
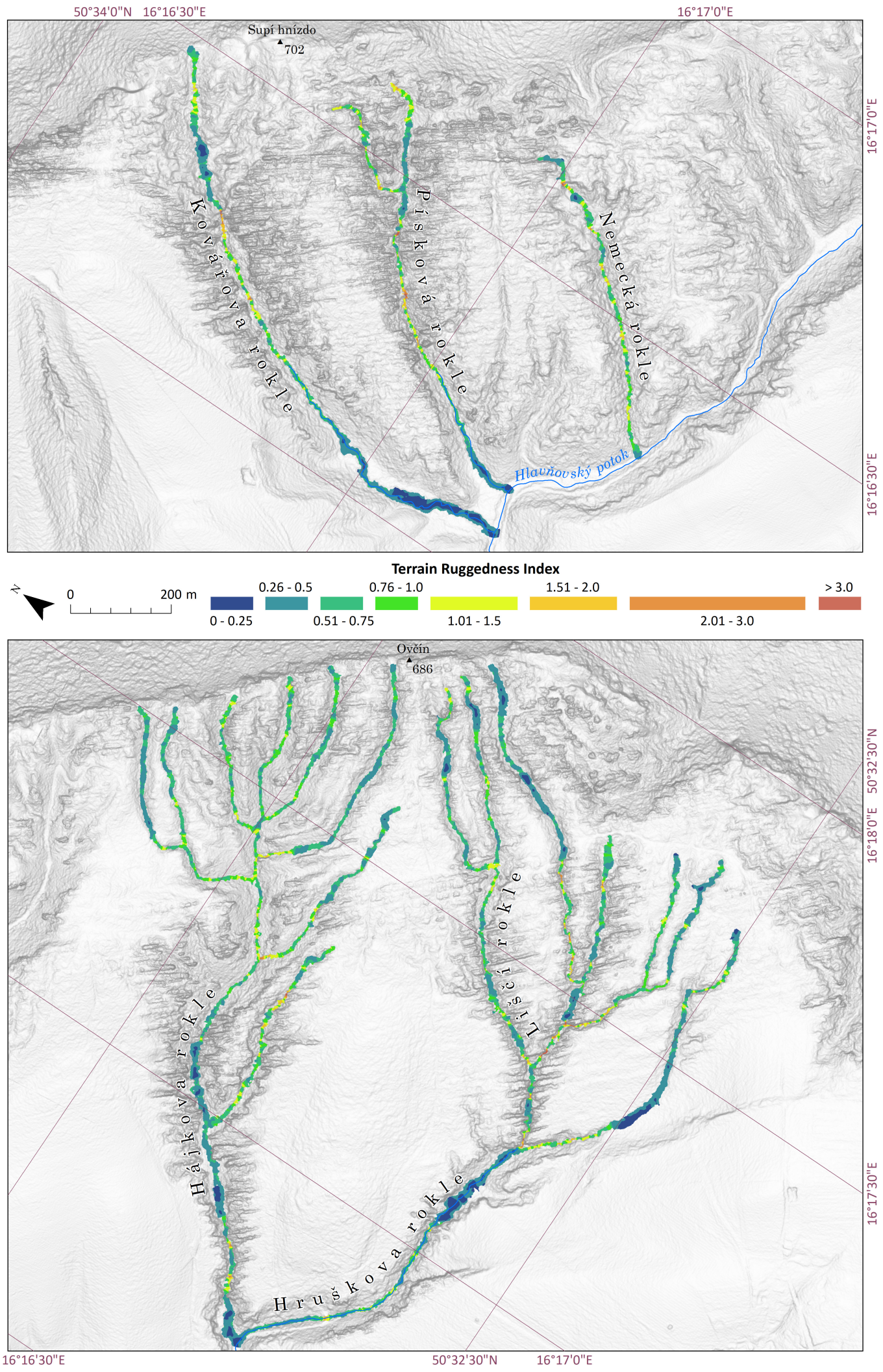

Fig. 10. Variability of Terrain Ruggedness Index along the length of canyon floors. TRI values in the range of $0.5-1.5$ correspond with the presence of boulder fills. 
More insight into geomorphology of the inter-canyon areas is offered by the map showing the presence of closed depressions, generated from the high-resolution DTM (Fig. 11). Two main observations are offered. First, floors of many side slots and passages host closed depressions, occasionally occurring one after another. Although field check indicated that some of these hollows are not really closed and there are narrow passages connecting with the main canyon (e.g., Fig. 11, site A), the dimensions of these depressions far exceed the width of a very narrow connecting slot. This suggests that surface connectivity between interfluve areas and the main canyons is limited, the hollows are effective sinks, and relatively little water and sediment transfer continues overland, via the narrow slot. Second, in various places on interfluves shallow ( 1 $\mathrm{m}$ deep) hollows occur. In the field they can be occasionally identified through waterlogging or marshy vegetation. They may occur irregularly, but in certain places they form a grid pattern, revealing adjustment to bedrock discontinuities (Fig. 11, site B). From a hydrological perspective they are sinks on seemingly planar water divide surfaces. Less regular is the distribution of closed depressions between the lower sections of the Kovářova, Písková and Nemecká gorges.

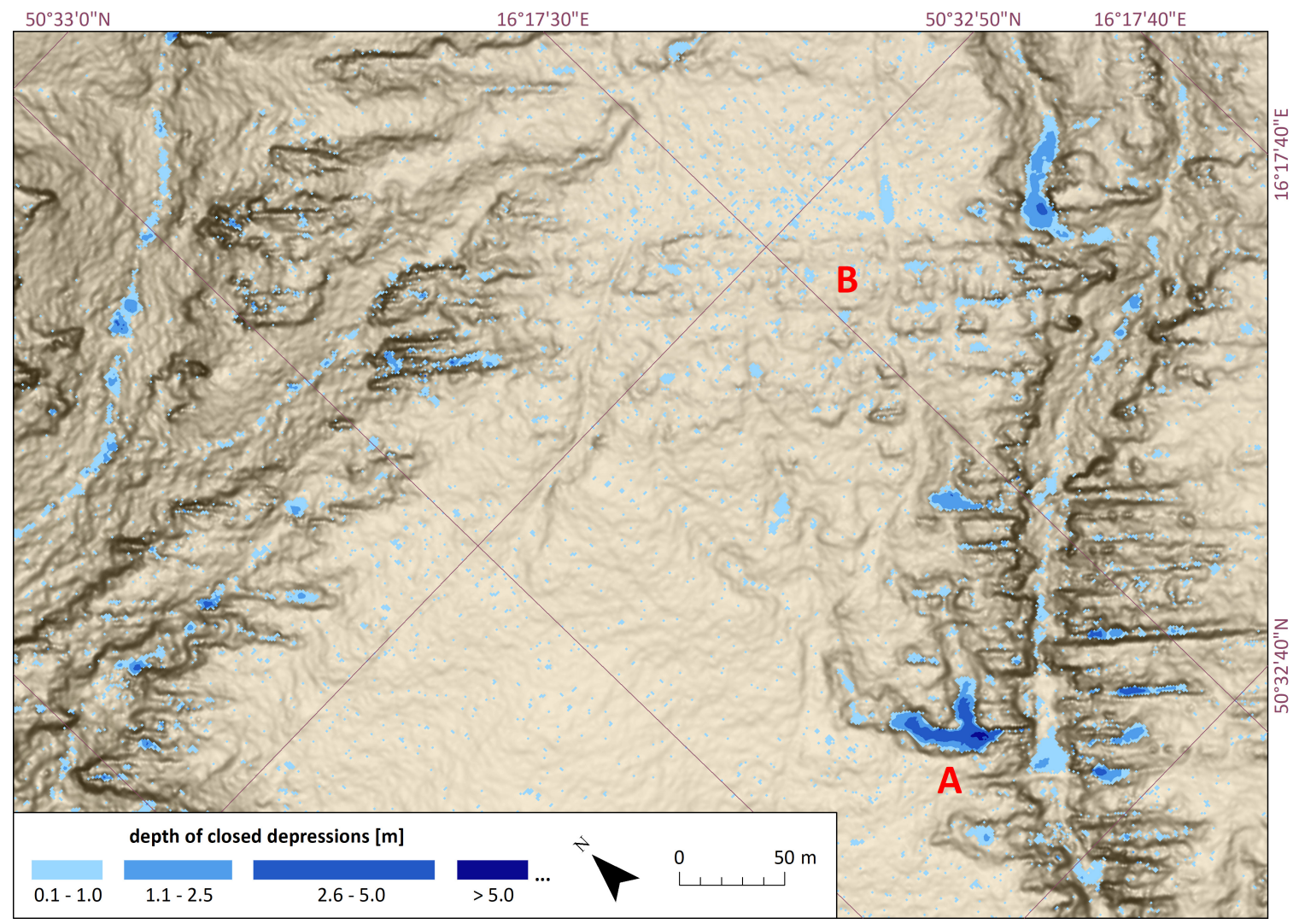

Fig. 11. Closed depressions in the inter-canyon area between the Hájkova Gorge and the Hruškova Gorge. See text for explanation of 'A' and 'B'.

\section{DISCUSSION - TOWARDS AN EVOLUTIONARY MODEL OF BOULDER-FILLED CANYONS}

\section{Rock fall hypothesis}

Two key observations emerge from data presentation. First, boulder fills are distinctive and significant parts of the canyon system within the cuesta backslope, not really accounted for in previous reports from the area. Not only are they prominent because of their spatial dimensions, but we propose that they convey an important message about the evolution of the system. Second, boulder caves cannot be successfully explained without considering their geomorphic context and setting, hence the evolution of fills and caves is intimately linked.

The existing literature seems to explain boulders within canyons and other types of valleys in rather simple way, as products of rock falls from canyon walls. Likewise, boulder caves are almost universally equated with talus caves, and the model of origin due to selective removal of fines, developed for granite caves, was not really transferred to sandstones. Indeed, the review of voluminous literature about sandstone pseudokarst has not revealed information about an origin of boulder caves other than due to mass movement (see Vitek, 1980; Bella, 2011). Accepting rock fall origin for in-valley boulder accumulations the following scenario is implied. A canyon is cut down by fluvial processes, then widened to produce a flat floor and lining rock faces. Rock fall from the latter, induced by whatever triggers, supplies boulders to the canyon floor and produces talus which may occasionally fill the entire canyon bottom. Piccini (1995) and Piccini \& Mecchia (2009) invoked rock fall as an essential process contributing to the origin of deep shafts in quartzite on tepui mountains in Venezuela. In their model, subterranean cavities produced by seepage and piping grow upward through successive roof collapses, as testified by boulder accumulations on the floors of the shafts. The shafts may then extend laterally, following major joints, to combine into the network of canyons close to the rims of the tepui. 
Subsequent collapses of intervening quartzite towers produce boulder fills in the canyon floors.

However, while not neglecting the occurrence of occasional rock falls and slides in the canyons of the Broumov Cliffs, it does not seem likely that catastrophic rock slope failures are responsible for the widespread boulder fills. The reasons to question the rock fall scenario are the following:

- boulder fills, although widespread, tend to occur in certain sections of the canyons rather than being randomly distributed along the length of the canyon. This is most striking in the Kovárova Gorge which can be divided into three sections, with the middle one being one continuous boulder fill, $550 \mathrm{~m}$ long;

- there are sections of canyons which have an extensive boulder fill and yet lack continuous lining rock walls. The middle-upper part of the Hájkova Gorge is an example;

- in some canyons, for instance in the Hruškova Gorge next to the confluence with the Lišči Gorge, evident talus at the angle of repose occurs but this is attached to the canyon sides and does not cover the flat floor;

- rock fall from sandstone cliffs usually results in considerable disintegration of boulders upon impact, the consequence of only moderate intact strength of sandstone (e.g., Schumm \& Chorley, 1966; Goudie et al., 2002; Migoń et al., 2005). There is little evidence that this happened here. Boulders making the fill are monolithic and rounded, with few dissecting fractures. Movement of rock blocks and boulders, if it occurred, was more likely to be slow;

- rock fall scars on canyon walls are infrequent and sharp edges are sporadic. Round shapes are much more common.

Consequently, rock fall origin for caves within the boulder fill does not seem relevant either. Big voids and labyrinthine networks of chambers and corridors are not expected in moderately strong rock (as the local sandstone is), if boulders were to crash following massive, instantaneous failures. Therefore, an assumption present in publications focused on the caves themselves (Vitek, 1980; Kopecký, 1990; Kopecký \& Jenka, 2013) that they are talus caves due to rock fall, may be questioned. Interestingly, the presence of an active stream in the cave lower storeys, although reported, was not considered an important part of the evolutionary story.

\section{Subsurface origin}

The above presented facts and considerations lead to the proposal of an alternative scenario that seems more applicable to the field situation. In this respect, narrow slots within the rims of the canyons appear particularly helpful, providing indirect evidence of what may have happened with the sandstone rock mass within the present day valley floor and hence what the likely origin of extensive boulder fills within canyons may be. Therefore, we first consider the probable evolutionary pathway of roofed slots (Fig. 12).
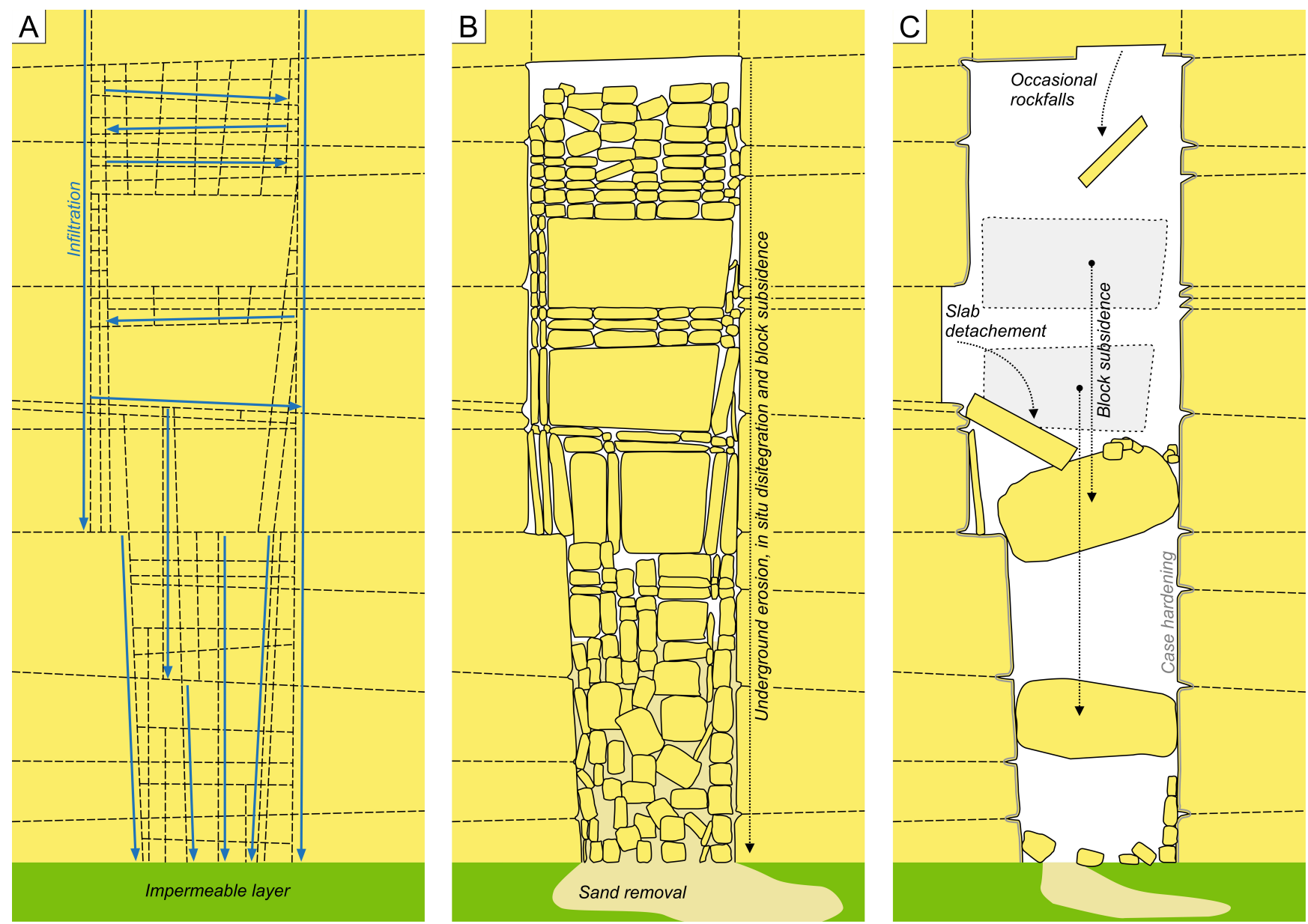

Fig. 12. Model of the development of roofed slots due to preferential weathering of more densely jointed sandstone compartments and removal of weathering products in the subsurface. 
The presence of slots is structurally controlled. They have developed within zones of very dense vertical and, less often, horizontal jointing that does not continue within the neighbouring sandstone compartments (see Fig. 5A, C). The sections of sandstone densely intersected by discontinuities were consequently the zones of preferential groundwater flow. Meteoric water infiltrating sandstone eroded the material along joint surfaces, grain-by-grain. It is possible that the detachment of individual minerals was preceded by chemical deterioration of cement and grain contacts due to a long reaction with water. Such a phenomenon, known as arenisation, has been described in a number of papers dealing with the evolution of quartz sandstone and quartzite terrains (e.g., Martini, 1979; Jennings, 1983; Wray, 1997; Wray \& Sauro, 2017). The underground removal of sandy detritus has led to formation of sandy sheets and cones at the outlets of slots. Such accumulations are common at the base of presently developing slots and vertical fissures (Fig. 13) and were recently described beneath the rock walls of the neighbouring Stołowe Mountains (Duszyński et al., 2016). The consequence of subsurface erosion is the in situ disintegration of sandstone rock mass, which, once solid, becomes divided into joint-bounded blocks and boulders of various dimensions. Continuous erosion leads to complete disintegration of the smallest compartments and the remaining material subsides into emerging voids, occupying lower and lower positions in an evolving slot. After a long (but undetermined) period of time the slot becomes nearly empty, with singular boulders at its bottom and the largest ones stacked between the lateral walls. More massive parts of sandstone often form roofs of the slots, testifying to the development of such forms from beneath (Fig. 5D). Occasional rock falls from the roof and slab detachment from case hardened vertical walls contribute to the enlargement of slots, but the importance of these processes appears secondary. This scenario is similar to the one proposed by Piccini (1995) in respect to the deep shafts within quartzite table mountains in Venezuela, although there are two differences. First, Piccini (1995) emphasizes the role of roof collapses into expanding voids, whereas gradual subsidence and sagging is proposed here. Second,

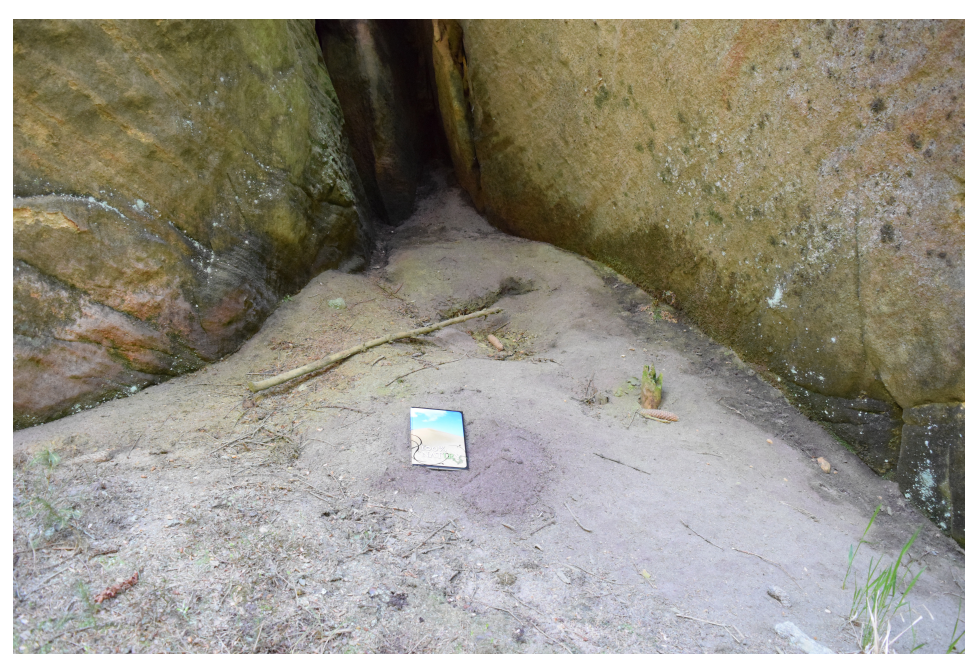

Fig. 13. An example of recent sand deposition next to the outlet of a fracture zone evolving into a slot (field notebook for scale). shafts are singular features, perhaps located at major joint intersections, whereas slots are linear features.

Bearing this in mind, we now reconsider the likely evolutionary pathway of larger landforms - the canyons themselves (Fig. 14). If the boulders filling the canyon floor are not of rock fall origin, as was explained before, and surface runoff is negligible in the area, other mechanisms must have been involved. It seems reasonable to suggest the following scenario. The zones of the present day canyons were subject to preferential groundwater flow. They might have been related to some structural controls or initial topographical patterns, but no firm answer can be provided now. Rain water was percolating through the sandstone, leading to enhanced weathering and erosion along joint surfaces and degradation of the internal structure of the rock. To some extent, this is a self-reinforcing process, as explained by the concept of reactive infiltration instability (Ortoleva et al., 1987). With time, flushing increases, weathering accelerates and voids (fractures, bedding planes) enlarge, focusing erosion along specific pathways. The sandstone becomes more and more disintegrated and the least resistant compartments turn into loose sand, removed by small streams flowing at depth. The continuous removal of material from beneath and the resultant subsidence of larger sandstone compartments explains the origin of extensive networks of voids and passages between the boulders. The concept assumes, therefore, that the development of canyons is not related to stream incision and successive collapses of blocks from valley sides. The material filling canyon floors should rather be considered as an in situ remnant of sandstone rock masses that were subject to intensive subsurface drainage and have thus become intensively disintegrated. The present position of boulders in the canyon floor - tens of metres beneath the rims of the valley side walls indicates how effective the process must have been.

The legitimacy of the presented model is supported by two other lines of evidence. First, the inter-canyon areas abound with closed depressions (Fig. 11). Their presence indicates that there must be another way of draining the area than surface runoff. Subsurface flow seems the only reasonable alternative. Water originating from the inter-canyon areas most probably supplies the canyon system. Second, the canyons in the study area locally lose their continuity and this is the case of the upper part of the Hruškova rokle. The uppermost part of the canyon is a well-developed valley that after c. 350 $\mathrm{m}$ from the head merges with the surrounding surfaces. No valley form can be followed for the next $200 \mathrm{~m}$ and then the canyon appears again, beginning with a distinctive valley head, with a spring. If the overland flow was the canyon formative mechanism, such a phenomenon would not be possible. Subsurface drainage is the viable explanation.

The development of the above model does not imply that all canyons or their sections evolved in this way. Long sections of canyon floors have negligible boulder fills (Fig. 8, 9). Rather, the 
evidence is presented to support the statement that the evolution of canyons in sandstone terrains may be complex and various development scenarios may be applicable in different places. Likewise, it is not to deny the role of episodic mass movements from the valley sides, such as rock falls or toppling. They surely contribute to the evolution of canyons in the Broumov Highland, but the field evidence suggests that their geomorphic role is minor.

The model presented here is an alternative to two concepts of canyon evolution present in the literature. It neither includes the crucial role of river incision nor does it imply the retreat of the canyon head due to groundwater sapping. The comparison with the latter case is particularly interesting because it proves that the action of underground water flow may support both catastrophic and non-catastrophic development of canyons. The seepage zone at the canyon rear walls of the Colorado Plateau causes episodic collapses (e.g., Laity \& Malin, 1985; Laity, 1988), whereas in the Broumov Highland the underground water leads to slow decay of sandstone and the removal of residuum. In fact, none of the canyons terminates with a distinctive head cut.

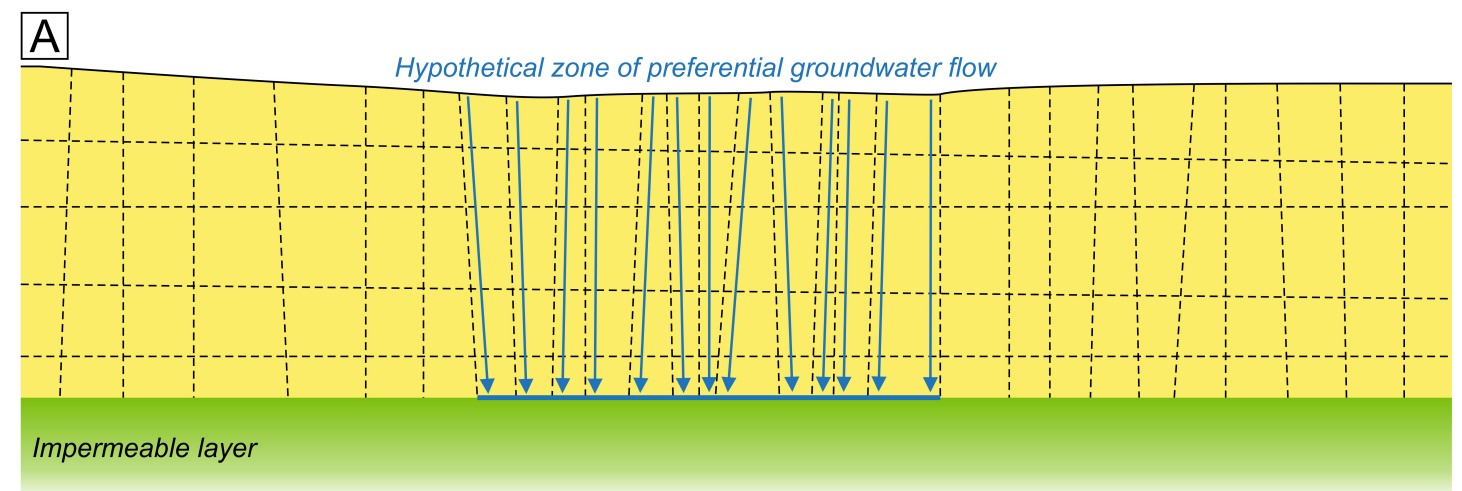

$\mathrm{B}$
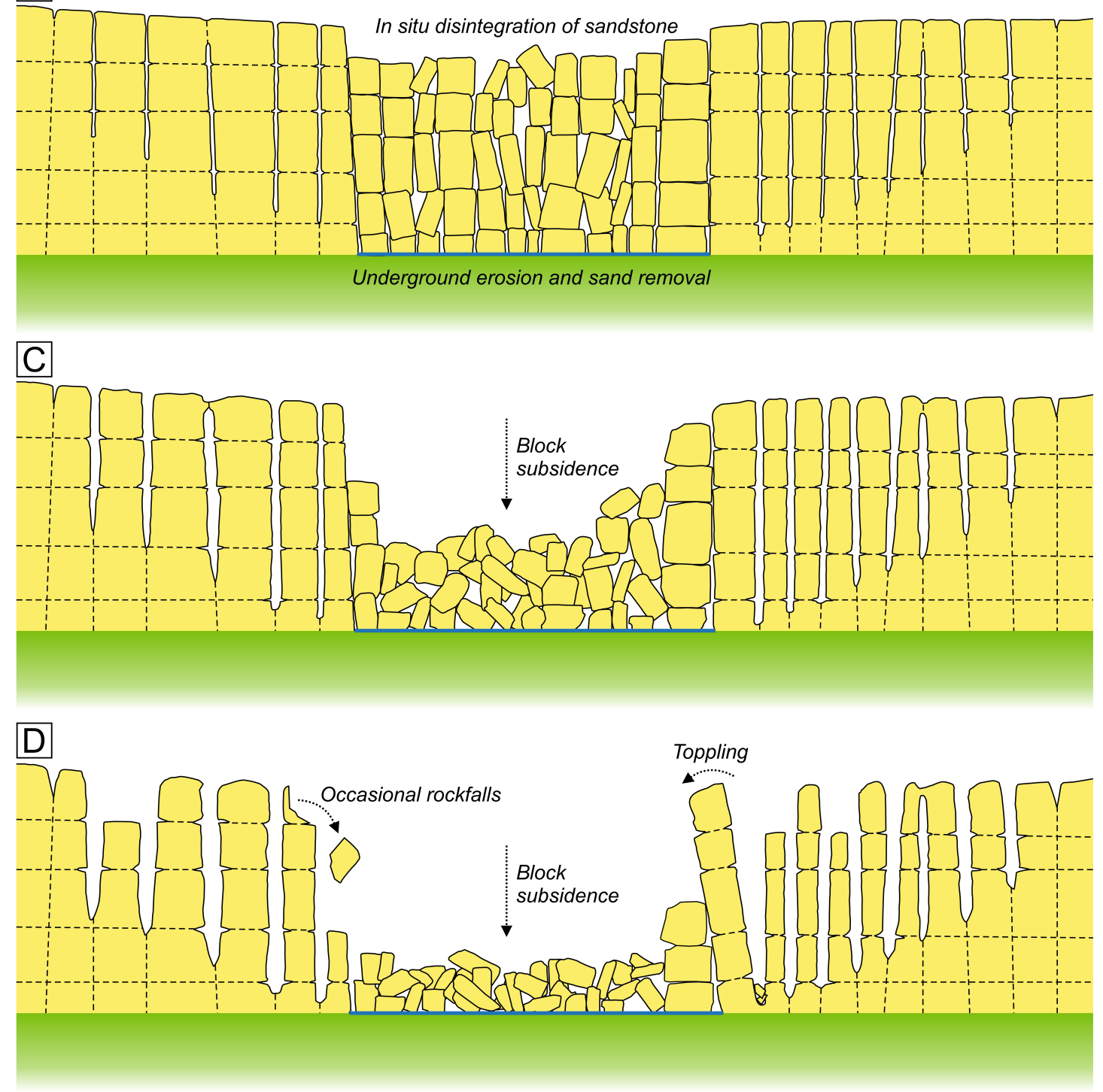

Fig. 14. Conceptual model of canyon deepening and lateral enlargement due to subsurface removal of fine material and sagging/subsidence of more massive compartments into emerging voids. 


\section{CONCLUSIONS AND OUTLOOK}

There is growing evidence worldwide that subsurface processes play an important part in the geomorphic evolution of sandstone terrains (Young et al., 2009; Bruthans et al., 2012b; Wray \& Sauro, 2017). Both dissolution and mechanical disintegration/removal of fines may be involved, accounting for a wide range of landforms. However, regarding underground morphologies the focus was mostly on large shafts and cave systems such as those present in quartzite mesas of Gran Sabana, Venezuela (Piccini, 1995; Piccini \& Mecchia, 2009; Sauro, 2014) or those genetically related to mass movements (Margielewski \& Urban, 2003, 2017; Lenart et al., 2014). Boulder caves were relatively neglected and usually explained as by-product of talus accumulation. In this paper, we use extensive field evidence from a canyon network incised into a sandstone cuesta backslope to develop a hypothesis of complex origin of massive boulder fills within the canyons. Subsurface rock mass disintegration and selective removal of grains by underground water are the core components of the evolutionary scenario. Thick boulder fills are explained as residual features rather than products of rock fall from canyon walls. Selective removal of fines leaves voids into which overlying blocks subside but the voids may be spacious enough (largely because the rock blocks are so large) to connect into penetrable caves. Following Bruthans et al. (2012a), the removal of material from beneath can be easily demonstrated for open and blind slots incised into the canyon walls but we claim that this pathway of evolution can be upscaled to the major landforms in the area - the canyons. In this way, a model of canyon evolution is offered, alternative to the existing models implying surface fluvial erosion or retreat due to spring sapping. Its applicability is limited by the thickness of a rock package and vertical distance to local base level, which control the efficacy of groundwater flow. Thus, in the Broumov Highland the origin of canyons a few tens of metres deep (up to $100 \mathrm{~m}$ or so) may be explained in this way, but in areas with thicker sandstone packages and more local relief, deeper canyons may possibly develop according to this scenario.

The model requires further testing and refinement, both in the study area and elsewhere. First, we are unable to address the timing and rates of the processes involved and hence, bracket the timescale of canyon evolution. An additional complication is imposed by major environmental changes which occurred in the Broumov Highland during the Quaternary. For instance, it may be hypothesized that subsurface processes were significantly reduced during the cold intervals of the Pleistocene, when permafrost occurred and may have sealed subsurface drainage routes. Second, hydrochemical studies of stream waters draining the canyons may shed some light on the effectiveness of silica dissolution under contemporary conditions, helping to constrain the timing of landform evolution. Third, a new look at boulder-filled canyons elsewhere would be a worthwhile exercise since, as demonstrated in this paper, rock fall hypothesis is not necessarily universally applicable.

\section{ACKNOWLEDGEMENTS}

This research was funded by the statutory fund available in the Institute of Geography and Regional Development, University of Wrocław (no. 1015/S) (for KJ and PM) and by research project no. 0420/2277/ 17 (for FD). At the time of this research, Filip Duszyński was a recipient of the doctoral scholarship ETIUDA of the National Science Centre, Poland (no. 2017/24/T/ ST10/00101). We are most grateful to Dr. Petr Kuna form the Broumovsko Protected Area for help and support offered to us during field work. Francesco Sauro and two anonymous reviewers are thanked for constructive comments offered on the first version of this paper.

\section{REFERENCES}

Bella P., 2011 - Genetické typy jaskýn̆. Verbum, Ružomberok, 220 p.

Bruthans J., Soukup J., Světlikk D., Schweigstillová J. \& Mayo A., 2012a - Zpevnené povrchy puklin v kvádrovém piskovci a jejich role pri vzniku skalnich mest. Zprávy o Geologických Výzkumech v Roce, 2012 (B): 109-115.

Bruthans J., Světlik D., Soukup J., Schweigstillová J., Valek J., Sedlačková M. \& Mayo A.L., 2012b Fast evolving conduits in clay-bonded sandstone: Characterization, erosion processes and significance for the origin of sandstone landforms. Geomorphology, 177: 178-193.

https://doi.org/10.1016/j.geomorph.2012.07.028

Campbell I.A., 1973 - Control of canyon and meander forms by jointing. Area, 5: 291-296.

Conrad O., Bechtel B., Bock M., Dietrich H., Fischer E., Gerlitz L., Wehberg J., Wichmann V. \& Böhner J., 2015 - System for automated geoscientific analyses (SAGA) v. 2.1.4. Geoscientific Model Development, 8 (7): 1991-2007.

https://doi.org/10.5194/gmd-8-1991-2015

Demek J., Jenka O. \& Kopecký J., 2006 - Specially protected pseudokarst areas in the Czech Republic. Nature Conservation, 63 (6): 95-100.

Duszyński F., Migoń P. \& Kasprzak M., 2016. Underground erosion and sand removal from a sandstone tableland, Stołowe Mountains, SW Poland. Catena, 147: 1-15.

https://doi.org/10.1016/j.catena.2016.06.032

Eberhard R.S. \& Sharples C., 2013 - Appropriate terminology for karst-like phenomena: the problem with 'pseudokarst'. International Journal of Speleology, 42 (2): 109-113.

https://doi.org/10.5038/1827-806X.42.2.2

Eszterhás I., 2009 - Oberflächliche Denudationsformen und Wollsack-höhlen im Granit des Velencei-Gebirges (Ungarn). Cadernos. Laboratorio Xeolóxico de Laxe, 34: 27-42.

Ford D.C. \& Williams P.W., 2007 - Karst hydrogeology and geomorphology. Wiley, Chichester, $562 \mathrm{p}$. https://doi.org/10.1002/9781118684986

Goudie A., Migoń P., Allison R.J. \& Rosser N., 2002 Sandstone geomorphology of the Al Quwayra area of south Jordan. Zeitschrift für Geomorphologie, 46: 365390. https://doi.org/10.1127/zfg/46/2002/365

Gregory H.E., 1917 - Geology of the Navajo country. US Geological Survey Professional Paper 93. 
Gregory H.E., 1950 - Geology and geography of the Zion Park region Utah and Arizona. US Geological Survey Professional Paper 220, 200 p. https://doi.org/10.3133/pp220

Halliday W., 2004 - Talus caves. In: Gunn J. (Ed.), Encyclopedia of karst and cave science. Fitzroy Dearborn, New York, p. 721-724.

Howard A.D., Kochel R.C., 1988 - Introduction to cuesta landforms and sapping processes on the Colorado Plateau. In: Howard A.D., Kochel R.C. \& Holt M.E. (Eds.), Sapping features of the Colorado Plateau. A comparative planetary geology field guide. NASA Scientific and Technical Information Division 1988, Washington DC, p. 6-56.

Jennings J.N., 1983 - Sandstone pseudokarst or karst. In: Young R.W. \& Nanson G.C., Aspects of Australian sandstone landscapes. Australian and New Zealand Geomorphology Group Special Publication, 1: 21-30.

Kopecký J., 1990 - Současný stav výzkumu pseudokrasu piskovcového reliéfu Broumovské vrchoviny. In: Wagner J. (Ed.), IV. Symposium o pseudokrasu. Sbornik referátů. Knihovna ČSS, , 23: 61-71.

Kopecký J. \& Jenka O., 2013 - Broumov Region. In: Adamovič J., Migoń P., Gołąb Z., Kopecký J., Jenka O., Mertlikk J., Peša V., Havránek P., Kukla J. \& Komaško A. (Eds.), Sandstone caves and rock cities of Bohemia. $16^{\text {th }}$ International Congress of Speleology, July 21-28, Brno, Czech Speleological Society, Prague, p. 4-12.

Laity J., 1988 - The role of groundwater sapping in valley evolution on the Colorado Plateau. In: Howard A.D., Kochel R.C. \& Holt M.E (Eds.), Sapping features of the Colorado Plateau. A comparative planetary geology field guide. NASA Scientific and Technical Information Division 1988, Washington DC, p. 63-70.

Laity J. \& Malin M.C., 1985 - Sapping processes and the development of theater headed valley networks on the Colorado Plateau. Geological Society of America Bulletin, 96: 203-217.

https://doi.org/10.1130/0016-7606(1985)96\%3C203: SPATDO \%3E2.0.CO;2

Lamb M.P., Howard A.D, Johnson J., Whipple K.X., Dietrich W.E. \& Perron J.T., 2006 - Can springs cut canyons into rock? Journal of Geophysical Research, 111 (E7): E07002.

https://doi.org/10.1029/2005JE002663

Lenart J., Pánek T. \& Dušek R., 2014-Genesis, types and evolution of crevice-type caves in the flysch belt of the Western Carpathians (Czech Republic). Geomorphology, 204: 459-476.

https://doi.org/10.1016/j.geomorph.2013.08.025

Margielewski W. \& Urban J., 2003 - Crevice-type caves as initial forms of rock landslide development in the Flysch Carpathians. Geomorphology, 54: 325-338. https://doi.org/10.1016/S0169-555X(02)00375-6

Margielewski W. \& Urban J., 2017 - Gravitationally induced non-karst caves: tectonic and morphological constrains, classification, and dating; Polish Flysch Carpathians case study. Geomorphology, 296: 160-181. https://doi.org/10.1016/j.geomorph.2017.08.018

Martini J.E.J., 1979 - Karst in Black Reef Quartzite near Kaapsehoop, Eastern Transvaal. Annals of the South African Geological Survey, 13: 115-128.

Migoń P., Duszyński F. \& Goudie A., 2017 - Rock cities and ruiniform relief: Forms - processes - terminology. Earth-Science Reviews, 171: 78-104. https://doi.org/10.1016/j.earscirev.2017.05.012

Migoń P., Goudie A., Allison R.J. \& Rosser N., 2005 - The origin and evolution of footslope ramps in the sandstone desert environment of south-west Jordan. Journal of
Arid Environments, 60: 303-320.

https://doi.org/10.1016/j.jaridenv.2004.03.011

Ortoleva P., Chadam J., Merino E. \& Sen A., 1987 Geochemical self-organization II: the reactive-infiltration instability. American Journal of Science, 287: 10081040. https://doi.org/10.2475/ajs.287.10.1008

Piccini L., 1995 - Karst in siliceous rocks: karst landforms and caves in the Ayuán-tepui (Est. Bolivar, Venezuela). International Journal of Speleology, 24: 2-13. https://doi.org/10.5038/1827-806X.24.1.2

Piccini L. \& Mecchia M., 2009 - Solution weathering rate and origin of karst landforms and caves in the quartzite of Auyan-tepui (Gran Sabana, Venezuela). Geomorphology, 106: 15-25.

https://doi.org/10.1016/j.geomorph.2008.09.019

Riley S.J., DeGloria S.D. \& Elliot R., 1999 - A terrain ruggedness index that quantifies topographic heterogeneity. Intermountain Journal of Sciences, 5: 23-27.

Sauro F., 2014 - Structural and lithological guidance on speleogenesis in quartz sandstone: evidence of the arenisation process. Geomorphology, 226: 106-123. https://doi.org/10.1016/i.geomorph.2014.07.033

Schumm S.A. \& Chorley R.J., 1966 - Talus weathering and scarp recession in the Colorado Plateaus. Zeitschrift für Geomorphologie, 10: 11-36.

Shaw P., 1980 - Cave development on a granite inselberg, South Rupununi Savannas, Guyana. Zeitschrift für Geomorphologie, 24: 68-76.

Sjöberg R., 1987 - Caves indicating neotectonic activity in Sweden. Geografiska Annaler, 68A: 393-398.

Stejskal V., Valenta V. \& Vilímek V., 2012 - Using geomorphological and geophysical survey to research relations between landforms and joint tectonics in the Broumovská urchovina (Czech Republic). AUC Geographica, 47 (1): 73-83. https://doi.org/10.14712/23361980.2015.26

Striebel T., 1995 - The genetic classification of some types of non-karstic caves. In: Preserving of Pseudokarst Caves. Proceedings of International Working Meeting, Rimavská Sobota - Salgótarján, p. 46-57.

Striebel T., 2008 - Granite caves in the Fichtelgebirge Mountains, Germany. Cadernos. Laboratorio Xeolóxico de Laxe, 33: 167-174.

Tásler R. (Ed.), 1979 - Geologie české části unitrosudetské pánve. Ústřední ústav geologický, Praha, 292 p.

Vidal Romaní J.R. \& Vaqueiro Rodrigues M., 2006 Types of granite cavities and associated speleothems: genesis and evolution. Nature Conservation, 63 (6): 41-46.

Vitek J., 1979 - Pseudokrasové tvary $v$ krídových piskovcich severovýchodnich Čech. Rozprávy ČSAV, MPV, 89 (4): 1-57.

Vitek J., 1980 - Typy pseudokrasových jeskyní v ČSR. Československý kras, 30: 17-28.

Wray R.A.L., 1997 - A global review of solutional weathering forms on quartz sandstone. Earth-Science Reviews, 42: 137-160.

https://doi.org/10.1016/S0012-8252(96)00056-6

Wray R.A.L. \& Sauro F., 2017 - An updated global review of solutional weathering processes and forms in quartz sandstones and quartzites. Earth-Science Reviews, 171: 520-557.

https://doi.org/10.1016/j.earscirev.2017.06.008

Yokoyama R., Shirasawa M. \& Pike R.J., 2002 Visualizing topography by openness: a new application of image processing to Digital Elevation Models. Photogrammetric Engineering and Remote Sensing, 68: $257-266$. 
Young R. \& Young A., 1992 - Sandstone landforms. Springer, Berlin, $163 \mathrm{p}$.

https://doi.org/10.1007/978-3-642-76588-9
Young R.W., Wray R.A.L. \& Young A.R.M., 2009 -

Sandstone landforms. Cambridge University Press,

Cambridge, 304 p. 